\title{
Runoff pollution impacts of polycyclic aromatic hydrocarbons in street dusts from a stream network town
}

\author{
Hongtao Zhao, Chengqing Yin, Meixue Chen and Weidong Wang
}

\begin{abstract}
$\overline{\text { ABSTRACT }}$
Runoff with contaminated street dusts has an environmental risk to the aquatic environment. An assessment of the diffuse pollution of polycyclic aromatic hydrocarbons (PAHs) from a small town and their risks to the township stream network was conducted at Yangtze River delta. This assessment is based on measurements of 16 PAHs from the US EPA priority list by GC-MS in stream water during rainy and dry season, street dusts with different particle sizes, river sediments and suspended solids of urban runoff. The maximum level of PAHs in the stream water $\left(2,323-4,948 \mathrm{~nL}^{-1}\right)$ were found during rainy season, while significantly lower PAHS concentrations (242-998 $\mathrm{ng} \mathrm{L}^{-1}$ ) were measured during dry season. The total PAHs ranged from 1,629 to $8,986 \mu \mathrm{g} \mathrm{kg}^{-1}$ in the street dusts. Approximately $55 \%$ of the total PAHs were associated with street dust particles of diameters less than $250 \mu \mathrm{m}$ and these accounted for $40 \%$ of the total. The town reaches sediments were rich in PAHs and it was suggested as the sink of street dusts. The research findings suggested that size of street dusts, the topographical and hydrological features of the landscape in the stream network were the important factors influencing PAH emitted to the receiving water. The contribution of urban surface runoff could significantly influence PAHs concentration in the stream water. To reduce the pollution of street dust into the stream network, the buffer zone along the hydrological pathway is suggested and the existing street cleaning methods should also be improved.
\end{abstract}

Key words | diffuse pollution, PAHs, stream network, street dust particle, urban runoff

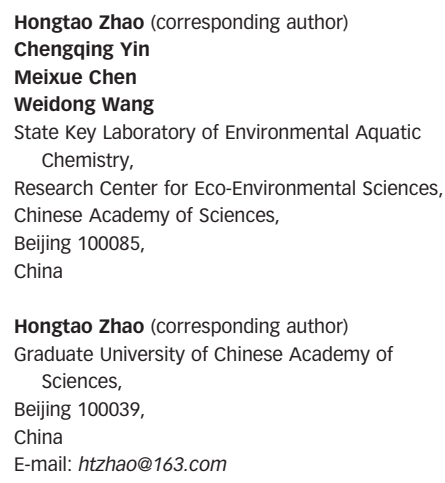

\section{INTRODUCTION}

Polycyclic aromatic hydrocarbons (PAHs) were a group of ubiquitous environmental pollutants some of which are known to be mutagenic or carcinogenic (Ravindra et al. 2008). Input of PAHs from point sources has gradually decreased because of enhanced discharge control (Schneider et al. 200I), while input of PAHs from urban stormwater runoff has been increasingly reported as one of the most frequent causes of surface water pollution (Murakami et al. 2004). Street dust particles in urban runoff act as a transport medium for PAHs (Brown \& Peake 2006).

Spatial patterns within landscapes, such as the location, distribution and proportions of watershed areas can crucially affect pollutants export (Yin et al. 1993; Wang et al. 2005). doi: 10.2166/wst.2008.814
Stream network is one of the important water shapes, extensively existing in big river deltas (Saco \& Kumar 2002), (Thomas et al. 2004). They have large land/water boundaries and most of polluted runoff can enter the water without buffer zones (Wiens 2002). The population density is usually heavy and these regions are under rapid urbanization. In China, most towns of stream network are rapidly industrializing and urbanization is increasing impervious areas. Abundant rainfall, and crisscrossed networks of canals accelerates the transport of street dust particles from the land surface to water bodies by surface runoff. In addition, the flow of water in stream networks is slow resulting in sediment accumulation (Salant et al. 2008). Unfortunately, some potential drinking 
water sources in this area have become contaminated by micropollutants such as PAHs by stormwater runoff (Chen et al. 2007). Thus, the stream network area, which is one of the most developed areas in East China, suffers from severe contamination of PAHs from non-point urban sources.

The objectives of this study were (1) to find the important fractions of particle-bound $\mathrm{PAH}$, (2) to look for the impact of street dust particle on receiving stream network.

\section{MATERIALS AND METHODS}

\section{Study site description}

The selected study site is Xincheng, a town on the Yangtze River delta and in Zhejiang Province in the southeastern
People's Republic of China (Figure 1). There is a warm and humid climate with four distinct seasons, sufficient sunshine and abundant rainfall. The mean annual temperature is $15.9^{\circ} \mathrm{C}$, the mean annual sunlight is $1,800-2,200$ hours and the average annual rainfall is $1,180 \mathrm{~mm}$. Xincheng is a typical town on the delta with the stream density is $3.5 \mathrm{~km} / \mathrm{km}^{2}$.

\section{Sample collection and size fractionating}

The study was conducted during 2006-2007. Street dust particles were collected with a vacuum cleaner between 9 and 10 a.m. after sweeping on March 26th, 2006. The mass of street dust per unit of street surface was measured. The sampling sites for street dust particles were distributed in the following typical sites: 3 in main traffic road streets

(a)

(b)
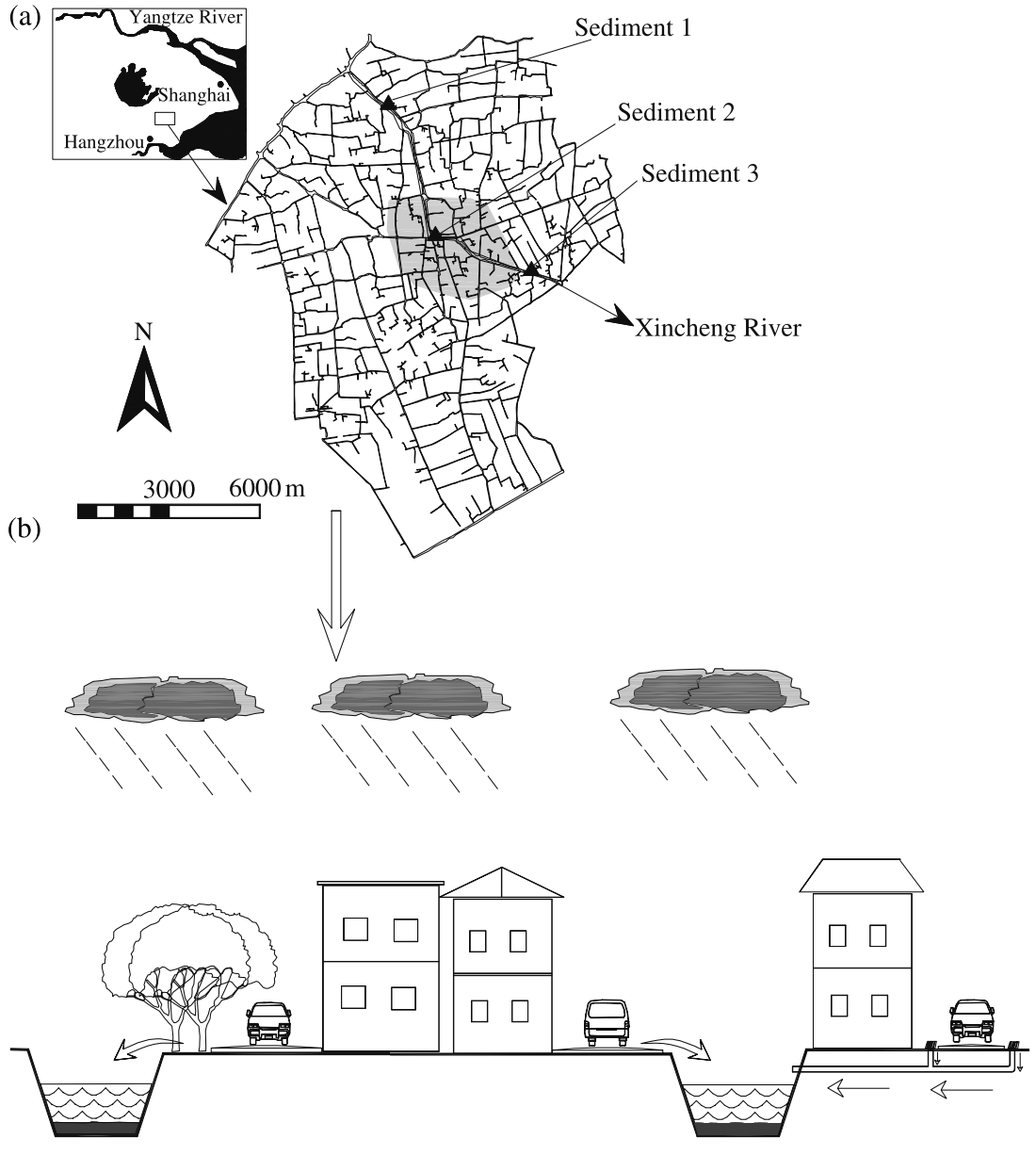

Figure 1 (a) Study area in Xincheng, a town with the dark shape in the stream network, the sediment sampling point at the Xincheng River, (b) a diagram of runoff in the stream network town with conduit flow and surface flow. 
(R1, R2, R3), 3 in industrial streets (I1, I2, I3), 3 in commercial streets $(\mathrm{C} 1, \mathrm{C} 2, \mathrm{C} 3), 2$ in old residential streets (OR1, OR2), 4 in new residential streets (NR1, NR2, NR3, NR4). Sites R1, R2, and R3 are paved with asphalt and the others with concrete. Polyester sieves were used for grain size fractionation. Samples were sorted into particle size fractions of $<63,63-125, \quad 125-250,250-900$ and $>900 \mu \mathrm{m}$. PAHs were analyzed for each particle size fractions, except the large fraction $>900 \mu \mathrm{m}$, which could be efficiently removed by the street sweepers (Sartor \& Boyd I972; Lau \& Stenstrom 2005).

Samples of the upper $15 \mathrm{~cm}$ of streambed sediment were collected using a stainless steel grab sampler, at three sites in the Xincheng River: upstream (sed1), within the town (sed2), and downstream (sed3) of Xincheng [Figure 1(a)], with two samples per site. Samples of the upper $10 \mathrm{~cm}$ of town soil were collected from four sites: roadside, kindergartens, public squares and fallow land. The content of town soil was an average value of the soils from the four sites (Table 1).

Samples of runoff water and river water were taken in June and August in 2007. $42 \mathrm{~mm}$ rain fell in 190 minutes on $6 / 13 / 2007$, and $22 \mathrm{~mm}$ of rain fell in 30 minutes on

Table 1 | Mass of street dust per unit area of street surface by grain size fraction for roads from several urban districts

\begin{tabular}{llllll}
\multicolumn{7}{c}{ Mass of street dust per area $\left(\mathbf{g} / \mathbf{m}^{\mathbf{2}}\right)$} & & \\
Land use* & $>\mathbf{9 0 0} \boldsymbol{\mu \mathbf { m }}$ & $\mathbf{2 5 0 - 9 0 0} \boldsymbol{\mu \mathbf { m }}$ & $\mathbf{1 2 5 - 2 5 0} \boldsymbol{\mu \mathbf { m }}$ & $\mathbf{6 3 - 1 2 5} \boldsymbol{\mu \mathbf { m }}$ & $<\mathbf{6 3} \boldsymbol{\mu \mathbf { m }}$ \\
\hline C1 & 0.4 & 0.9 & 0.5 & 0.4 & 0.3 \\
C2 & 1.4 & 2.6 & 0.8 & 0.5 & 0.3 \\
C3 & 5.2 & 7.5 & 2.5 & 1.7 & 0.6 \\
I1 & 0.7 & 3.5 & 2.5 & 1.9 & 0.9 \\
I2 & 9.5 & 10.3 & 2.6 & 1.3 & 0.5 \\
I3 & 7.8 & 9.5 & 3.2 & 1.7 & 0.8 \\
NR1 & 2.5 & 6.5 & 1.5 & 1.0 & 0.5 \\
NR2 & 1.2 & 6.0 & 2.1 & 0.9 & 0.3 \\
NR3 & 2.8 & 1.7 & 0.5 & 0.4 & 0.5 \\
NR4 & 0.5 & 0.9 & 0.4 & 0.3 & 0.2 \\
OR1 & 1.0 & 3.1 & 1.7 & 1.7 & 1.2 \\
OR2 & 4.2 & 5.1 & 2.1 & 1.5 & 0.8 \\
R1 & 1.0 & 2.5 & 1.1 & 0.5 & 0.1 \\
R2 & 1.1 & 6.0 & 3.5 & 2.3 & 0.9 \\
R3 & 8.1 & 7.5 & 3.0 & 1.8 & 0.6 \\
\hline
\end{tabular}

${ }^{*} \mathrm{C}, \mathrm{I}, \mathrm{NR}$, OR and R represent: commercial, industrial, new residential, old residential streets and main traffic roads.
$8 / 24 / 2007$. Runoff samples were taken manually at catch basins in the streets with an interval of 3 minutes in the first 30 minutes followed by 10 minute intervals until runoff ceased. At the same time, river water samples were also taken from Xincheng River before and during the rain events. Runoff volume was measured using calibrated polythene barrel with $20 \mathrm{~L}$ for higher volumes and $5 \mathrm{~L}$ for smaller volumes during rainfall events. Water samples were collected in plastic bottles and were analyzed in the laboratory within 5 days of the sampling. Details of sampling were similar to that of Wang et al. (2005) and Zhao et al. (2007).

Event mean concentration (EMC) is used to estimate the pollution loads in the runoff. It is a flow-weighted average of constituent concentration to characterize runoff pollution (Sansalone \& Buchberger I997), and calculated as

$\mathrm{EMC}=\frac{\int_{0}^{1} C(t) \times Q(t) \mathrm{d} t}{\int_{0}^{1} Q(t) \mathrm{d} t}$

where, EMC is the event mean concentration $(\mathrm{mg} / \mathrm{L}) ; C(t)$ is the time variable concentration $(\mathrm{mg} / \mathrm{L}) ; Q(t)$ is the runoff flow rate discharged at time $\left(\mathrm{m}^{3} / \mathrm{min}\right)$.

\section{Analytical methods}

The standards used were 16 USEPA priority PAHs [naphthalene (Nap), acenaphthylene (Acy), acenaphthene (Ace), fluorine (Fl), phenanthrene (Phe), anthracene (An), fluoranthene (Flu), pyrene (Pyr), benzo[a]anthracene (BaA), chrysene (Chr), benzo[b]fluoranthene $(\mathrm{BbF})$, benzo[k]fluoranthene $(\mathrm{BkF})$, benzo[a]pyrene $(\mathrm{BaP})$, indeno[1,2,3-cd]pyrene (Inp), diben$\mathrm{zo}[\mathrm{a}, \mathrm{h}]$ anthracene (DBA), and benzo[ghi]perylene $(\mathrm{BgP})]$ in a solution of $2,000 \mu \mathrm{g} / \mathrm{mL}$ and surrogate standards (acenaphthene-d10, phenanthrene- $\mathrm{d} 10$, chrysene-d12, perylene$\mathrm{d} 12$ ) in a mixture solution of $500 \mu \mathrm{g} / \mathrm{mL}$. Both were purchased from Supelco (USA). All organic solvents of pesticide analytical grade were obtained from Fisher Co. (USA).

Street dust particles, sediment and soil samples were extracted with a Soxhlet apparatus. Each sample $(10 \mathrm{~g})$ was spiked with four surrogate standards (acenaphthene-d10, phenanthrene-d10, chrysene-d12, perylene-d12), and then extracted with $200 \mathrm{~mL}$ of methylene chloride for $48 \mathrm{~h}$, to which activated copper was added for desulphurization. The extract was pre-concentrated to $2 \mathrm{~mL}$ by a rotary 
evaporator and the solvent was exchanged with hexane. The hexane extract was fractioned and cleaned up using an LCSi SPE Tube (Supelco Co. Cat. No. SP7953C) capped with anhydrous sodium sulfate $(1 \mathrm{~cm})$. The tubes were eluted with $70 \mathrm{~mL}$ of methylene chloride/hexane (vol/vol $=3: 7$ ) to obtain PAHs. The PAH fraction was finally concentrated to $1 \mathrm{~mL}$ under a gentle stream of nitrogen.

The concentrations of PAHs in the extracts were determined using an Agilent 6890 gas chromatograph (GC) equipped with a splitless injector, HP-5 capillary column $(30 \mathrm{~m} \times 0.25 \mathrm{~mm}$ inner diameter $\times 0.25 \mu \mathrm{m}$ film thickness $)$ and a 5973 mass selective detector (MSD). The carrier gas was helium (ultra high purity) at a constant flow rate of $1 \mathrm{~mL} / \mathrm{min}$. The GC oven temperature was programmed from $50^{\circ} \mathrm{C}(2 \mathrm{~min})$ to $200^{\circ} \mathrm{C}(2 \mathrm{~min})$ at $20^{\circ} \mathrm{C} / \mathrm{min}$, then to $240^{\circ} \mathrm{C}(2 \mathrm{~min})$ at $5^{\circ} \mathrm{C} / \mathrm{min}$ before reaching $290^{\circ} \mathrm{C}$ at $3^{\circ} \mathrm{C} / \mathrm{min}$ and held for $15 \mathrm{~min}$. The injector and detector temperatures were $280^{\circ} \mathrm{C}$ and $300^{\circ} \mathrm{C}$, respectively. Chromatographic data were collected and processed using HP Chemstation software. Detection limits were $1.1-5.3 \mu \mathrm{g} / \mathrm{kg}$ dry weight for PAHs. All the results were expressed on a dry weight basis.

Total organic matter $(\mathrm{OM})$ was determined by ignition at $550^{\circ} \mathrm{C}$ for $2 \mathrm{~h}$. The density of the street dust particles was measured with a pycnometer.

\section{RESULT}

The PAH contents in street dust particles, urban soil and river sediment

The contents of total PAHs in street dust particles $(<900 \mu \mathrm{m})$ ranged from 1,629 to $8,986 \mu \mathrm{g} / \mathrm{kg}$, with a mean of $4,130 \mu \mathrm{g} / \mathrm{kg}$ (Figure 2) in the Xincheng stream network. Of the five land use types, the dust particles collected from industrial area streets (I) had the highest PAH contents, while that from the new residential areas (NR) had the lowest. The magnitude of $\mathrm{PAH}$ contamination varied greatly in the sediments from different reaches of Xincheng River. Much higher total PAH concentrations were found in the town reach sediment (sed2). The town reach sediment (sed2) contained comparable amounts of PAHs to street dust particles, and the sediments from upstream and downstream reaches, and the town soil contained much lower PAH concentrations.

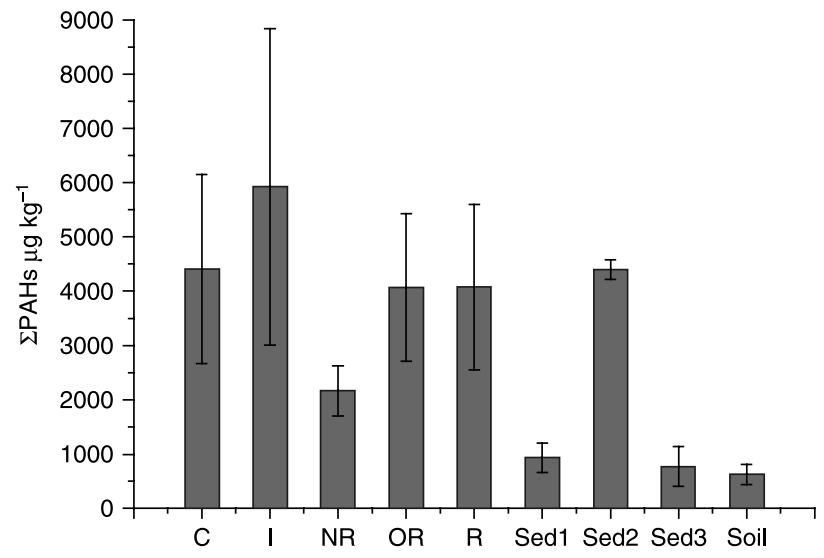

Figure 2 | Total PAHs contents in street dust particles, river sediments and urban soil. C, I, NR, OR and R represent: commercial, industrial, new residential, old residential streets and main traffic roads; sed1, sed2 and sed3: the sediments from the upstream, town section and downstream of the Xincheng River; soil: the town soil.

\section{PAH contents of particle size fractions of street dust}

The total PAHs and density in street dust particles with different size fractions showed a grain size gradient (Figure 3). Density varies from 1.62 to $1.85 \mathrm{~g} / \mathrm{cm}^{3}$ in the four size-fractions. Higher contents of PAHs and smaller density occur in street dust particles with smaller grain size. It is suggested that they have high mobility in runoff and they are easily transported to the stream network (Murakami et al. 2005). Approximately 55\% of total PAH were present in particles with diameters of less than $250 \mu \mathrm{m}$, accounting for $40 \%$ of the street dust particle weight.

\section{Risk assessment and mobility of street dust particle to receiving water}

To assess PAHs pollution in street dust particles and stream sediments, the results were interpreted using the effects range low (ERL) and the effects range median (ERM) values as defined elsewhere (Long et al. 1995). Table 2 shows that several PAH components contents in street dust, suspended sediment in runoff and streambed sediments are above the ERL and thus may moderately impact the biota health of stream network. Several PAHs in the street dust with the diameter less than $63 \mu \mathrm{m}$ and suspended sediment of runoff are above the ERM, and these may severely impact biota health. The smaller street dust particles have even higher $\mathrm{PAH}$ content and it is expected that if the runoff 


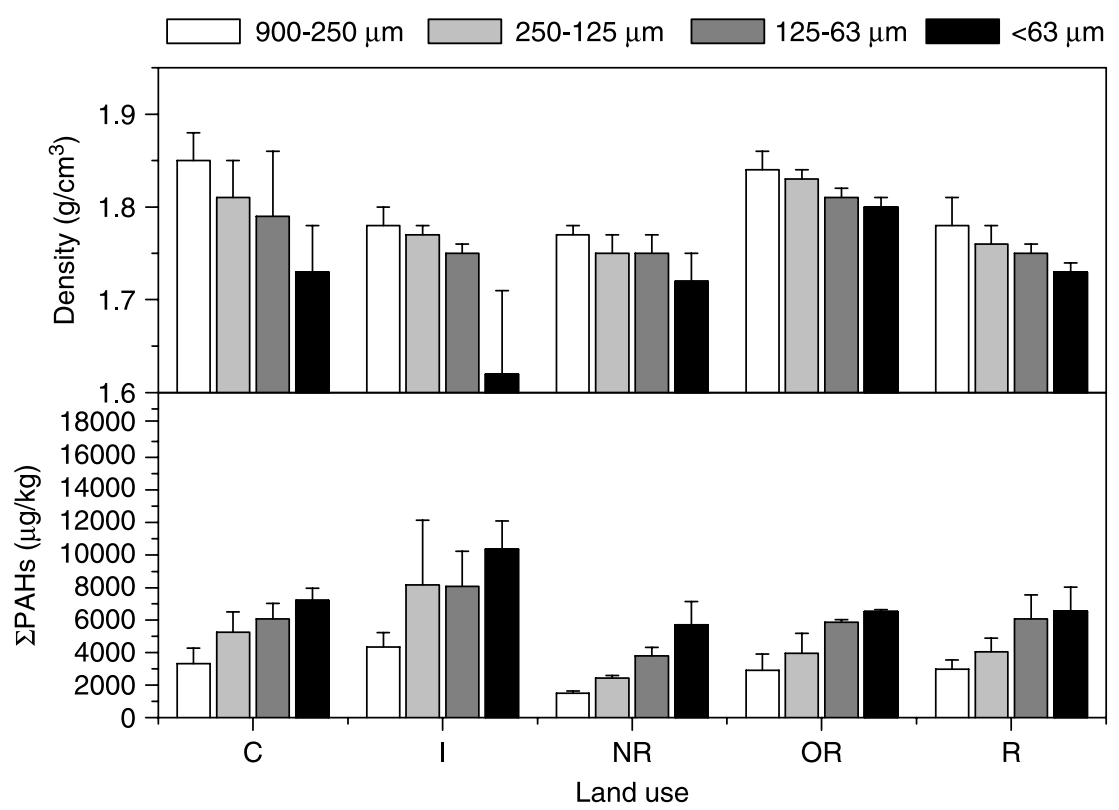

Figure 3 The density of street dust particles and total PAH contents in the size-fractions of the street dust particles (C, I, NR, OR, R have the same meaning as in Figure 2).

Table 2 Pollution criteria of PAH components for sediment matrix $(\mu \mathrm{g} / \mathrm{kg}$ ) suggested by Long et al. (1995) and Wang et al. (2005). Several PAH components are in the range between ERL and ERM where toxic effects were possible

\begin{tabular}{|c|c|c|c|c|c|c|c|c|c|c|c|}
\hline Compound & ERL & ERM & sed1 & sed2 & sed3 & ss1 & SS2 & $<63 \mu \mathrm{m}$ & $125-63 \mu \mathrm{m}$ & $250-125 \mu \mathrm{m}$ & $900-250 \mu \mathrm{m}$ \\
\hline Nap & 160 & 2,100 & 28 & 147 & 19 & 393 & $\underline{410}$ & 322 & 365 & $\underline{389}$ & 223 \\
\hline Acy & 44 & 640 & 7 & 9 & 2 & 19 & $\underline{96}$ & $\underline{86}$ & $\underline{83}$ & 72 & 43 \\
\hline Ace & 16 & 500 & 2 & $\underline{36}$ & 3 & $\underline{27}$ & $\underline{58}$ & 33 & 30 & 29 & 17 \\
\hline $\mathrm{Fl}$ & 19 & 540 & 12 & 83 & 8 & 245 & 211 & 158 & 139 & 123 & 73 \\
\hline Phe & 240 & 1,500 & 74 & $\underline{576}$ & 28 & 1,919 & 768 & $\underline{1,022}$ & $\underline{1,035}$ & $\underline{858}$ & 587 \\
\hline An & 853 & 1,100 & 16 & 78 & 6 & 158 & 89 & 168 & 172 & 161 & 113 \\
\hline Flu & 600 & 5,100 & 126 & 525 & 81 & 2,249 & 836 & 925 & $\underline{698}$ & 540 & 353 \\
\hline Pyr & 665 & 2,600 & 102 & 454 & 109 & 2,423 & 533 & 645 & 483 & 395 & 271 \\
\hline $\mathrm{BaA}$ & 261 & 1,600 & 92 & 318 & 62 & 7,956 & $\underline{1,215}$ & 364 & 283 & 218 & 167 \\
\hline $\mathrm{CHr}$ & 384 & 2,800 & 125 & 457 & 122 & 647 & 511 & 613 & 467 & 366 & 195 \\
\hline $\mathrm{BbF}$ & NA & NA & 153 & 585 & 156 & 4,657 & 1,020 & 917 & 736 & 531 & 224 \\
\hline $\mathrm{BkF}$ & NA & NA & 53 & 234 & 38 & 2,003 & 685 & 315 & 227 & 124 & 76 \\
\hline $\mathrm{BaP}$ & 430 & 1,600 & 113 & 358 & 95 & 78 & 236 & 537 & 370 & 246 & 157 \\
\hline InP & NA & NA & 1 & 76 & 7 & 9,111 & 1,339 & 229 & 160 & 142 & 65 \\
\hline DBA & 63 & 260 & 1 & 222 & 2 & 6,457 & 4,140 & 436 & 208 & 176 & 180 \\
\hline BgP & NA & NA & 30 & 245 & 30 & 4,265 & 1,322 & 491 & 377 & 288 & 164 \\
\hline Total & 4,000 & 44,792 & 934 & 4,402 & 767 & 42,608 & 13,470 & 7,261 & 5,835 & 4,660 & 2,909 \\
\hline
\end{tabular}

NA: not available; The underlined data are above the ERL or ERM values. 
continues washing the street dust particles into the river, the sediment $\mathrm{PAH}$ content would probably continue to increase.

Due to the slow flow of water in the stream network, street dust particles in urban runoff accumulate in the sediments close to the point of entry into the network. Figure 2 shows that the town reach sediment (sed2) had much higher total PAHs content than the sediments in the upstream and downstream reaches.

Surface runoff caused by rainfall contributes PAHs to the receiving water. This pollution is mostly in particulate form. Street dusts make a great contribution to the urban runoff particulate pollutants. The particle-bound PAHs account, on average, for $94.7 \%$ and $93.6 \%$ of total PAHs in two rainfall events in June and August in 2007 (Table 3).

The urban runoff water affects the water quality of Xincheng River markedly in the town reach during heavy rainfall events (Table 4) and the particle-bound PAHs account for the most. It was observed that the total PAHs concentrations in the stream increased 43\%-62\% during the rainfall events, and more than half of the increase was from particulate matter. Because the heavy rainfalls do not generate high flows in the stream networks, large-sized particles are deposited at runoff entry sites and accumulate there. This is probably the reason why the town reach sediments (sed2) have much higher contents of PAHs than the sediments in the upstream and downstream reaches (Figure 2).

Buffer zones between the pollution sources and the receiving water can control pollutant transport ( $\mathrm{Lu}$ et al. 2007). The distances between the sampling sites and the receiving water are small, and those distances and the pathways by which street dust particles enter the receiving water, are shown in Figure 1(b). The street dust mobilized by stormwater enters receiving water by either direct surface flow or conduit flow. The increasing size of impervious areas in the town could generate a high runoff. There are usually no buffer zones between the street and the receiving water in this town. The PAHs in street dust were quickly washed into the receiving water.

Stream networks in large river deltas have special hydrological characteristics. In this area, the plain land is divided into many small pieces by the stream channels. The slope of streams is very low and the flow velocity is affected by many factors. Because there are many flow routes and wetlands in the stream network, the peak velocity is greatly reduced after rainfall. It was observed that there was small flow, no flow or back flow in Xincheng River, even during rainfall events. The mean levels of PAHs in the water in May and July ranged from 1,956 to $2,582 \mathrm{ng} / \mathrm{L}$ while in

Table 3 | Event mean concentration (EMC) of total suspended sediment (TSS) and PAHs contents in runoff water during two rainfall events

\begin{tabular}{|c|c|c|c|c|c|c|c|}
\hline Date of rain event & Land use & PAHs forms & $2+3$ ring (\%) & 4 ring (\%) & 5 + 6 ring (\%) & 乏PAH ng/L & TSS mg/L \\
\hline \multirow[t]{3}{*}{$6 / 13 / 2007$} & $\mathrm{R}$ & Dissolve & 47 & 28 & 24 & 1,675 & \\
\hline & & Particle & 15 & 29 & 56 & 30,195 & 425 \\
\hline & & Total & 17 & 29 & 54 & 31,870 & \\
\hline \multirow[t]{12}{*}{$8 / 24 / 2007$} & $\mathrm{R}$ & Dissolve & 32 & 25 & 42 & 811 & \\
\hline & & Particle & 23 & 22 & 55 & 5,686 & 283 \\
\hline & & Total & 30 & 22 & 48 & 6,497 & \\
\hline & $\mathrm{C}$ & Dissolve & 31 & 22 & 47 & 738 & \\
\hline & & Paritcle & 14 & 29 & 57 & 18,099 & 455 \\
\hline & & Total & 18 & 29 & 54 & 18,837 & \\
\hline & I & Dissolve & 26 & 37 & 37 & 630 & \\
\hline & & Particle & 17 & 30 & 52 & 27,852 & 585 \\
\hline & & Total & 14 & 29 & 57 & 28,482 & \\
\hline & NR & Dissolve & 19 & 26 & 56 & 611 & \\
\hline & & Particle & 26 & 36 & 38 & 8,115 & 292 \\
\hline & & Total & 18 & 29 & 53 & 8,717 & \\
\hline
\end{tabular}


Table 4 | Total suspended sediment (TSS) and total PAHs contents (in $\mathrm{ng} / \mathrm{L}$ ) in Xincheng River before and during two rainfall events

\begin{tabular}{|c|c|c|c|c|c|c|c|c|c|c|c|}
\hline \multirow[b]{2}{*}{ Date of rain event } & \multirow[b]{2}{*}{ PAHs forms } & \multicolumn{2}{|c|}{ TSS } & \multicolumn{2}{|c|}{$2+3$ ring } & \multicolumn{2}{|c|}{4 ring } & \multicolumn{2}{|c|}{$5+6$ ring } & \multicolumn{2}{|c|}{ ¿PAHS } \\
\hline & & B.R & D.R & B.R & D.R & B.R & D.R & B.R & D.R & B.R & D.R \\
\hline \multirow[t]{3}{*}{$6 / 13 / 07$} & Particle & & & 346 & 484 & 91 & 153 & 145 & 522 & 582 & 1,159 \\
\hline & Dissolve & 35 & 131 & 723 & 975 & 117 & 219 & 392 & 347 & 1,232 & 1,542 \\
\hline & Total & & & 1,070 & 1,459 & 208 & 372 & 537 & 869 & 1,815 & 2,701 \\
\hline \multirow[t]{3}{*}{$8 / 24 / 07$} & Particle & 38 & 230 & 286 & 532 & 54 & 281 & 796 & 1,105 & 1,136 & 1,918 \\
\hline & Dissolve & & & 181 & 283 & 39 & 67 & 166 & 198 & 386 & 547 \\
\hline & Total & & & 467 & 814 & 93 & 348 & 962 & 1,303 & 1,522 & 2,465 \\
\hline
\end{tabular}

November and January significant lower PAHs concentrations were measured (311-475), which suggested that PAHs contamination in water was heavier during rainy season than during dry season (in Table 5). One of possible explanations could be the increased surface runoff and atmospheric deposition in rainy season.

\section{$\overline{\text { DISCUSSION }}$}

The size of the street dust particles is a critical factor affecting the pollutant's mobility and remove efficiency. The behavior of street dust in runoff depends on its grain size-distribution (Furumai et al. 2005; Murakami et al. 2005). Street dust makes a great contribution to the runoff pollutant load (Stone \& Marsalek 1996; Walker et al. 1999; Rocher et al. 2004). The smaller street dust particles have

Table 5 | PAHs contents in Xingcheng River during rainy and dry seasons (ng/L)

\begin{tabular}{|c|c|c|c|c|c|c|}
\hline Sampling time & & Compound & $2+3$ ring & 4 ring & $5+6$ ring & इPAHS \\
\hline \multirow[t]{6}{*}{ Rainy season } & Jul & Particle & 62 & 29 & 9 & 1,555 \\
\hline & & Dissolve & 45 & 45 & 10 & 1027 \\
\hline & & Total & 55 & 35 & 9 & 2,582 \\
\hline & May & Particle & 70 & 23 & 7 & 1,420 \\
\hline & & Dissolve & 76 & 22 & 2 & 562 \\
\hline & & Total & 71 & 23 & 6 & 1,956 \\
\hline \multirow[t]{6}{*}{ Dry season } & Jan & Particle & 52 & 40 & 8 & 154 \\
\hline & & Dissolve & 89 & 9 & 2 & 158 \\
\hline & & Total & 71 & 24 & 5 & 311 \\
\hline & Nov & Particle & 58 & 29 & 13 & 213 \\
\hline & & Dissolve & 82 & 16 & 2 & 262 \\
\hline & & Total & 72 & 22 & 7 & 475 \\
\hline
\end{tabular}

higher PAHs contents due to greater surface area per volume and to higher organic matter contents, indicative of pollutant adsorption onto dust particles (Hoffman et al. 1982; Roger et al. 1998; Andral 1999).

Street dust has environmental impact to receiving waters and management actions should be taken to reduce the pollution at the sources. However, Xincheng town streets are swept with a push broom. The previous researchers found that this method is only effective for removal of large particles and is ineffective for small particles with high PAHs contents.

In this research, it was found that the PAHs contents in suspended sediment in runoff were even higher than less than those in less than $63 \mu \mathrm{m}$ fraction, suggesting that the diameter of suspended sediment particles in runoff was probably much smaller. Larger dust particles are deposited onto the bed sediment; smaller particles remain in suspension longer and could be transported to the drinking water plant farther downstream in the Xincheng River, bringing a health threat to local communities. For this reason, we suggest actions should be considered to reduce the transport of street dust pollution to the stream network.

\section{$\overline{\text { CONCLUSION }}$}

Smaller street dust particle had higher content of total PAHs, and lower densities, higher mobility and PAHs contamination during urban runoff. The high density of channels in the area, short distance between the streets and the receiving waters and the absence of buffer zones accelerated the street dust particles transfer from the streets into the stream network. 
Urban runoff was one of the import reasons for higher PAHs concentration in the stream water in rainy season.

\section{ACKNOWLEDGEMENTS}

This research was supported by the Key Project of Zhejiang Province (2006C13057) and the Key Project of the Knowledge Innovation Programme of CAS (KZCX1-YW-06-02). The authors are grateful to Jiaxing Academy of Agriculture Sciences and the Bureau of Water Resources of Jiaxing City for their field assistance.

\section{REFERENCES}

Andral, M. C. 1999 Particles size distribution and hydrodynamic characteristics of solid matter carried by runoff from motorways. Water Environ. Res. 71, 398-407.

Brown, J. N. \& Peake, B. M. 2006 Sources of heavy metals and polycyclic aromatic hydrocarbons in urban stormwater runoff. Sci. Total Environ. 359(1-3), 145-155.

Chen, Y., Zhu, L. \& Zhou, R. 2007 Characterization and distribution of polycyclic aromatic hydrocarbon in surface water and sediment from Qiantang River, China. J. Hazard. Mater. 141(1), 148-155.

Furumai, H., Jinadasa, H. K., Murakami, M., Nakajima, F. \& Aryal, R. K. 2005 Model description of storage and infiltration functions of infiltration facilities for urban runoff analysis by a distributed model. Water Sci. Technol. 52(5), 53-60.

Hoffman, E. J., Latimer, J. S., Mills, G. L. \& Quinn, J. G. I982 Petroleum hydrocarbons in urban runoff from a commercial land use area. J. Water Pollut. Control Fed. 54, 1517-1525.

Lau, S. L. \& Stenstrom, M. K. 2005 Metals and PAHs adsorbed to street particles. Water Res. 39(17), 4083-4092.

Long, E. R., Macdonald, D. D., Smith, S. L. \& Calder, F. D. 1995 Incidence of adverse biological effects within ranges of chemical concentrations in marine and estuarine sediments Environ. Manage. 19(1), 81-97.

Lu, H., Yin, C., Wang, W. \& Shan, B. 2007 A comparative study of nutrient transfer via surface runoff from two small agricultural catchments in north China. Environ. Geol. 52(8), 1549-1558.

Murakami, M., Nakajima, F. \& Furumai, H. 2004 Modelling of runoff behaviour of particle-bound polycyclic aromatic hydrocarbons (PAHs) from roads and roofs. Water Res. 38(20), 4475-4483.

Murakami, M., Nakajima, F. \& Furumai, H. 2005 Size-and densitydistributions and sources of polycyclic aromatic hydrocarbons in urban road dust. Chemosphere 61(6), 783-791.
Ravindra, K., Sokhi, R. \& Van Grieken, R. 2008 Atmospheric polycyclic aromatic hydrocarbons: source attribution, emission factors and regulation. Atmos. Environ. 42, 2895-2921.

Rocher, V., Azimi, S., Moilleron, R. \& Chebbo, G. 2004 Hydrocarbons and heavy metals in the different sewer deposits in the 'Le Marais' catchment (Paris, France): stocks, distributions and origins. Sci. Total Environ. 323(1-3), 107-122.

Roger, S., Montrejaud - Vignoles, M., Andral, M. C., Herremans, L. \& Fortune, J. P. 1998 Mineral, physical and chemical analysis of the solid matter carried by motorway runoff water. Water Res. 32, 1119-1125.

Sartor, J. D. \& Boyd, G. B. 1972 Water pollution aspects of street surface contaminants. US EPA Office of Research and Monitoring. Repor EPA-R2-72-081.

Salant, N. L., Hassan, M. A. \& Alonso, C. V. 2008 Suspended sediment dynamics at high and low storm flows in two small watersheds. Hydrol. Processes 22, 1573-1587.

Saco, P. M. \& Kumar, P. 2002 Kinematic dispersion in stream networks: 1. coupling hydraulic and network geometry. Water Resour. Res. 38(11), 1244-1255.

Sansalone, J. J. \& Buchberger, S. G. 1997 Partitioning and first flush of metals in urban roadway storm water. J. Environ. Eng. 123(2), 134-143.

Schneider, A. R., Stapleton, H. M., Cornwell, J. \& Baker, J. E. 20oI Recent declines in PAH, PCB, and toxaphene levels in the northern Great Lakes as determined from high resolution sediment cores. Environ. Sci. Technol. 35(19), 3809-3815.

Stone, M. \& Marsalek, J. 1996 Trace metal composition and speciation in street sediment: Sault Ste Marie, Canada. Water Air Soil Pollut. 87(1-4), 149-169.

Thomas, S. M., Neill, C., Deegan, L. A., Krusche, A. V., Ballester, V. M. \& Victoria, R. L. 2004 Influences of land use and stream size on particulate and dissolved materials in a small Amazonian stream network. Biochemistry 68(2), 135-151.

Walker, W. J., McNutt, R. P. \& Maslanka, C. K. 1999 The potential contribution of urban runoff to surface sediments of the Passaic River: sources and chemical characteristics. Chemosphere 38(2), 363-377.

Wang, X. H., Yin, C. Q. \& Shan, B. Q. 2005 The role of diversified landscape buffer structures for water quality improvement in an agricultural watershed, North China. Agric. Ecosyst. Environ. 107(4), 381-396.

Wiens, J. A. 2002 Riverine landscapes: taking landscape ecology into the water. Freshw. Biol. 47(4), 501-515.

Yin, C., Zhao, M., Jin, W. \& Lan, Z. 1993 A multi-pond system as a protective zone for the management of lakes in China. Hydrobiologia 251(1), 321-329.

Zhao, J. W., Shan, B. Q. \& Yin, C. Q. 2007 Pollutant loads of surface runoff in Wuhan City Zoo, an urban tourist area. J. Environ. Sci. (China) 19(4), 464-468. 